Jojak Vol 12 (1) (2019):33-53 DOI: https://doi.org/10.15294/jejak.v12i1.17677
http://journal.unnes.ac.id/nju/index.php/jejak

\title{
Economic Development of Mangosteen Agro-Industry Based on Sustainability
}

\author{
Parwa Oryzanti $^{1 凶}$, Ernan Rustiadi $^{2}$, Eriyatno3, Nurul Taufiqu Rochman ${ }^{4}$ \\ 'Study Program of Natural Resource and Environment Management Post-Graduate School of Institute \\ of Agriculture Bogor \\ ${ }^{2}$ Faculty of Agriculture, Institute of Agriculture Bogor \\ 3Study Center of Agriculture and Rural Development ( $\mathrm{PSP}_{3}$ ), Institute of Agriculture Bogor \\ ${ }^{4}$ Physics Research Center, the Indonesian Institute of Science
}

Permalink/DOI: https://doi.org/10.15294/jejak.v12i1.17677

Received: October 2018; Accepted: January 2019; Published: March 2019

\begin{abstract}
The concept of developing agro-industry based agropolitan area for Mangosteen Peel Extract is a solution to create the high added value and to increase people's income in the area. Agro-industry development in agropolitan areas by optimizing the local strategic commodities is a breakthrough to support the regional economy growth to be sustainable, so it is common in accordance with the potential regional leading commodities. The aim of this research is to analyze the sustainability of the area and to assess the feasibility of mangosteen agro-industry investment. The results of analysis show that the level of sustainability of technological and infrastructure, economic, social, and environmental and technological aspects are categorized as less sustainable with the sustainability index ranging from $34.12 \%$ to $49.96 \%$. While the policy aspects in the development of Karacak agropolitan area are categorized as unsustainable with the sustainability index of $22.31 \%$. The results of the feasibility analysis show that the capsulated agro-industrial product of mangosteen peel extract have greater opportunity to attract the investors because it is feasible with NPV value of Rp 17,690,067,855 and the added value of Rp 90,833/ kg of raw materials..
\end{abstract}

Key words : Agropolitan Approach, Agro-Industry, Mangosteen, Regional Economy.

How to Cite: Oryzanti, P., Rustiadi, E., Eriyatno, E., \& Rochman, N. (2019). Economic Development of Mangosteen Agro-Industry Based on Sustainability. JEJAK: Jurnal Ekonomi dan Kebijakan, 12(1), $33-53$. doi:https://doi.org/10.15294/jejak.v12i1.17677

\footnotetext{
Corresponding author:

Address: Jl. Raya Dramaga, Babakan, Bogorı West Java

p-ISSN 1979-715X

668o

e-ISSN 2460-5123

E-mail: riceoryzanti@gmail.com
} 


\section{INTRODUCTION}

Poverty and economic, social, and cultural gap between the city and rural society become one strategic issue in the national development plan. The emergence of agropolitan concept through the Acts No. 26 in 2007 on Layout, supported by the Regulation of Minister of Agriculture No. 50 in 2012 on the Guide of Area Development, becomes a strategy to build the agricultural area in rural areas by increasing the value added of the area, decreasing the imbalance of welfare, harmonizing rural-city development, strengthening rural agro-business activities, and increasing the people's participation in the area. Rural areas have potential abundant natural resources and natural charm become the attractiveness for people to be willing to stay inside.

The problem is that the potential has not been maximally developed. Dominant and major livelihood on farm and the undeveloped off farm become the challenge to be solved. The agricultural products that can only be sold in raw materials cause many leakage of the value added to the city. This makes the rural areas not developed. Whitby (1984) and Friedman (1966) present that in the rural development process the main thing to be concerned is that agricultural sector is the economic base in the rural area. The relation with agropolitan is that the starting point if this is the (agricultural) basic sector development in the frame of the area development. The follow-up, the processing industries and the supporting services are developed in accordance with the rural environment. It is in line with the balanced development principle between the agricultural and industrial sectors. (Mubyarto,1993).

The chain of life in rural level should be strived for by establishing the sustainable agrobusiness activities and building the proper residential centers in order to support people's welfare. It is strengthened by Rustiadi and Dardak (2008) that agropolitan development is aimed at increasing the agricultural products and sales of agricultural products, supporting the growth of small-medium scaled agro-processing industry, and encouraging the varied economic activities of the market center, so that those will create the value added for the sustainability of the agropolitan areas to be something significant.

The value added creation for the agricultural commodities is conducted by processing it into a product having higher value and competitiveness, which is known as agro-industry. The definition of agro-industry is presented by Austin (1981) that is a company processing the vegetable materials (originated from plants) or animal ingredients (produced by animals). The process used covers alteration and preservation through physical or chemical treatment, storage, packaging, and distribution.

Such frame can be completed by some factors those are planning, production process, and marketing. The production process should be brought closer to the technique and application of green productivity (GP) to the agro-industry. In Marimin et.al. (2015), it is mentioned that to establish a business that can answer the social demand on the quality of life through supplying the goods and service produced by sustainable ways. The focus of GP on the small middle companies, in which 
UKM become the backbone of business in Asia. UKM is a key to the overall economy development in the whole Asia. GP focuses on creating the relationship among environment, quality, and profitability. It is explained by Sadjad (2005), all this time the development in agricultural sector using the extension device has not targetted yet in the change in attitude, but still in the level of using the modern agricultural device. There is no change in attitude and mindset from subsistent to agroindustry. Agro-industry here is a village as the base of raw materials to be established into agro-industry base in which there is a value added process to the agricultural product such as sorting, standardization of product, packaging, service, and transportation.

Rustiadi, et.al. (2011) suggest that the significance of agropolitan area development is closely related to the idea of Marimin, et.al (2015) about the issues mentioned above. Both opinions, if related to the concept of industrial village by Sadjad (2005), will bring a new concept that can bridge the aim of rural area and agro-industry development in a big circle of natural and environment resource management sustainability.

The agropolitan area planned by the government becomes a positive effort in bringing the progress in the village. However, the aspects supporting the agropolitan area have not been simultaneously collaborated yet those are settlement and agrobusiness aspect as the main aspect forming the definition of agropolitan, as presented by Rustiadi (2004). One of agrobusiness functions is agricultural product processing or known as agro-industry. Afterwards, what kind of agro-industry model that can be developed and can involve the people in agropolitan area? Considering that the agro-industry built must be in the agropolitan area, the next question is what kind of role model to make the agro-industry possible to be conducted by the people around the area, and also to be dominated and even to be owned by them. The existence of agroindustry can give utility and value added for the increase in income of the area and also can decrease the massive economic leakage. One of the requirements is that the agro-industry should be beneficial and appropriate based on the investment criteria and could be implemented by the people in the agropolitan area. The idea of agro-industry agropolitan development is a big concept to grow an economy in rural level and to create employment in the village.

The agro-industry developed is based on the local resources, or optimizing the leading commodities owned by the agropolitan area. In this research, Karacak agropolitan has mangosteen commodity. All this time mangoesteens are sold in fresh condition either at the local market or the export market. The value added owned by the people in the agropolitan area is still dominant in the cultivation business and not sourced from the post-harvest processing activitiies or the agroindustry, so that there is still leakage in the value added that can be overcome through the mangosteen based agro-industry activity.

For the sustainability and preservation of life environment in the agropolitan area, the approach of technique and application of green productivity concept and zero waste is applied to plan the frame of production process for the agro-industry. The concept of green productivity is introduced for the first time by Asian Productivity Organization (APO) in 1994 as the respond to the needs on 
relationshipbetween the strategy of economy development and the environment preservation.The problems in model development of the sustainable agro-industry agropolitan area involve various complex elements, among others are the natural resources (SDA), the environmental resources (SDL), the social resources (SDS), the human resources (SDM), the technological resources (SDT) and the economic resources (SDE). All these elements are the composer of agroindustry agropolitan system. In order to be able to analyze the needs and interest of various elements to reach the same goal, this research is conducted through System Approach.

According to Eriyatno (2012), in the mechanism of joining the system, the activity moves from an individual to be a group's effort to bear various terminologies in management sector such as: interaction, inter-disciplinary, interface, interrelated, interconnectivity, and the most famous coordination. Systematic thinking covers the process of thinking of a purpose, a goal, and a target in one's mind covering interaction of element, component, and sub-system to form a system.

In this research, the feasibility analysis on agro-industry investment is conducted by the financial feasibility method to make an economic study of mangosteen peel that is the consumption waste or the mangosteen food processing valuable in health or business prospect in the agropolitan area. The aim of this research is : (1) analyzing the condition of sustainable status of Karacak agropolitan area and (2) analyzing the feasibility and the value added of mangosteen peel based agroindustry.

\section{RESEARCH METHOD}

This research is conducted in Bogor Regency since July 2017 until August 2018. The case study is at Karacak Agropolitan Area, Karacak Village, Leuwiliang District. The case study of mangosteen agro-industry is conducted in UMKM and industry scale. The UMKM scale is mangosteen dodol and mangosteen peel extract floor soap located in Karacak agropolitan area. While the agroindustry scale at PT Zena Nirmala Sentosa producing the same products with Garcia brand is located at Jl. Raya Cicadas No. 51, RT o1/o2 Cicadas Village, Gunung Putri District, Bogor Regency.

Table 1. Category of Sustainable Index

\begin{tabular}{ll}
\hline Index Value & Sustainable Category \\
\hline $0-25$ & Bad; Unsustainable \\
$26-50$ & Less; Less Sustainable \\
$51-75$ & Enough; Enough Sustainable \\
$76-100$ & Good; Very Sustainable
\end{tabular}

Source: Pitcher (1999)

The sustainable level analysis uses Multidimensional Scaling Analysis (MDS) (Young, 2009; Borg and Groenen, 1997). The sustainable status of Karacak agropolitan area is stated in the form of sustainable index based on the Rap-Agro approach by applying the MDS technique. The Rap-Agro approach is modified from the Rapfish (Rapid Assessment Techniques for Fisheries) Method developed by the Fisheries Center, University of British Columbia (Fauzi and Anna, 2005). MDS method is a statistic analysis technique that transforms each dimension and multidimension into the sustainable dimension of agro-industry agropolitan system. This research is aimed having a description of the 
sustainable level of agropolitan area development in Karacak, Bogor Regency. The step of MDS analysis is presented in Table 2.

Table 2. Steps of MDS Analysis

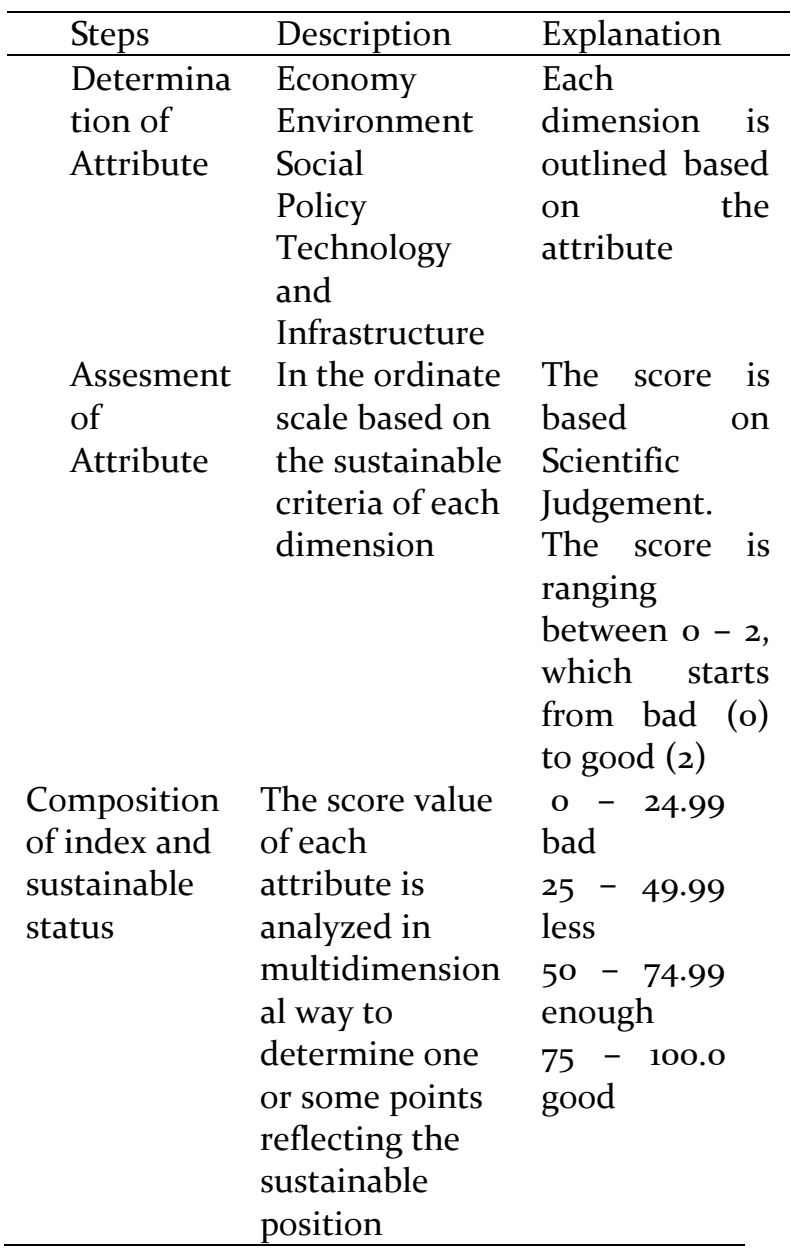

Afterwards, the assesment method of investment feasibility is used to determine the agro-industry investment feasibility status using the financial feasibility criteria including Net Present Value (NPV), Intenal Rate of Return (IRR), B/C Ratio, Break Even Point (BEP), Pay Back Periode (PBP) referring to Gray et.al (1992) and Gittinger (1982) in Rustiadi, et.al.(2011). There are some choices of mangosteen-based agro-industry which feasibility has been tested. The result of analysis then becomes one of inputs in reaching the next purpose so that the criteria of product to hold an agropolitan area can be widened into the social, environmental, technological and infrastructure, institutional or any other factors that can be found in the time of field observation.

The net value of $\mathrm{B} / \mathrm{C}$ ratio bigger than one is a requirement to make a project feasible in finance so it can be continued, on the contrary, if the value is smaller than one. It is a sign that the project is not feasible to be conducted (Gray, et.al, 1992). According to Sofyan (2002), PBP technique is used to determine how long the capital planted in a business will be back.

If the alternative of cash flow is found from the business proposed again, the alternative suggestion of business that gives the shortest period is the best. The Break Even Point (BEP) analysis is used determine the volume of production or sales as minimum as possible to make the expense is the same with the benefit found (Gray et. al, 1993)

Afterwards, to see the elasticity of a project of agro-industry, a sensitivity analysis is conducted. This analysis is conducted by changing the value of a parameter on a time to further see how the effect on the acceptability of investment. The parameters that usually change and change can affect the decision are investment expense, cash flow, rest value, interest rate, tax rate, economic condition, et cetera (Umar, 2007). The criteria of financial feasibility of agro-industry is summarized in Table 3. In this research a sensitivity analysis is conducted to the change of interest rate, raw material expense, and decrease in product price. By taking two scenario those are (1) the product price is stable, but the raw material price and the interest rate are increased, and 
(2) the product price is decreased, the raw material price is increased, and the interest rate is increased. The investment feasibility study can be used to calcultae the economic value added of the area. The economic value added of the area is analyzed using Hayami method.

Table 3. Criteria of Financial Feasibility of

\begin{tabular}{ll}
\multicolumn{2}{c}{ Agro-Industry } \\
$\begin{array}{l}\text { Parameter of } \\
\text { Feasibility }\end{array}$ \\
\hline PBP (Year) & $\begin{array}{l}\text { Lower than the } \\
\text { required time } \\
\text { More than o (nol) }\end{array}$ \\
NPV (Rp) & $\begin{array}{l}\text { More than } 1 \text { (satu) } \\
\text { B/C Ratio }\end{array}$ \\
& $\begin{array}{l}\text { Bigger from the } \\
\text { walking interest } \\
\text { IRR (\%) }\end{array}$ \\
& rate
\end{tabular}

\section{RESULTS AND DISCUSSION}

Karacak agropolitan area is located in Bogor Regency, precisely at Leuwiliang District. Geographically Bogor Regency has an area on $298,838.304$ hectare, located between

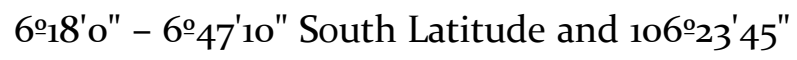
- 107 ${ }^{\circ} 13^{\prime} 30^{\prime \prime}$ East Longitude. This area at the South is bordering with South Tangerang City, Tangerang Regency, Depok City, and Bekasi Regency/City. At the West it is bordering with Lebak Regency; at the East it is bordering with Karawang Regency, Cianjur Regency and Purwakarta Regency. At the South it is bordering with Sukabumi Regency and Cianjur Regency; while at the Middle it is bordering with Bogor City. Leuwiliang District has an area of 9,143.39 hectare, or about 3\% of Bogor Regency, with the administrative border at the North is Leuwisadeng District, at the West is Nanggung District, at the South is Banten
Province and at the East is Cibungbulang District and Pamijahan District.

Bogor Regency has varied type of area morphology, from the relatively lowlands at the North to the highlands at the South.about $\mathbf{2 9 . 2 8 \%}$ at the height of 15 -100 meter above the sea level (dpl), $42.62 \%$ at the height of $100-500$ meter dpl, 19.53\% at the height of $500-1,000$ meter dpl, $8.43 \%$ at the height of 1,00o-2,00o meter dpl and $0.22 \%$ at the height of $2,000-$ 2,500 meter dpl. Besides, the morphology condition of Bogor Regency mostly is the highlands, the hills, and the mountains with the building blocks dominated by the results of volcanic eruption covering andesit, tufa and basalt. The combined stone is included in the nature of relatively pass water stone, in which its feature of steeping the rain water is great. The type of this weathering stone is relatively vulnerable to the movement of the ground if receiving the steady high rainfall. Afterwards, the type of land covering is dominated by the rather sensitive and very sensitive off volcanic materials to the erosion, among others are Latosol, Aluvial, Regosol, Podsolik and Andosol. Therefore, some areas are vulnerable to the landslide.

The area width of Bogor Regency based on the land use pattern is grouped into: mixed garden of $85,202.5$ ha $(28.48 \%)$, built area/settlement of $47,831.2$ ha (15.99\%), shrubs of $44,956.1$ ha (15.03\%), dense vegetation forest /plantation of $57,827.3$ ha $(19.33 \%)$, irigation farm/raid fed of 23,794 ha (7.95\%), empty land of $36,351.9$ ha $(12.15 \%)$.

Administratively, Bogor Regency has 40 districts including 417 villages and 17 subdistricts (434 villages/sub-districts), covered in 3,882 Citizen Association and 15,561 Neighborhood Association. In 2012 four new 
villages have been built those are Pasir Angin Village, Megamendung District, Urug Village and Jayaraharja Village Sukajaya District and Mekarjaya Village Rumpin District. Leuwiliang District administratively has eleven villages those are Purasari, Puraseda, Pabangbon, Karyasari, Karacak, Barengkok, Cibeber I, Cibeber II, Leuwimekar, Leuwiliang, and Karehkel.

The amount of residents of Bogor Regency based on the data of Central Bureau of Statistics (BPS) in 2016 is $5,587,390$ people, covering 2,856,529 male people and 2,730,861 female people. In 2015 there are 5,459,668 people, which means that in 2016 there is an increase of $2.34 \%$ compared with 2015. From the data of potential population, Leuwiliang District has a projection of total population of 121,597 people covering 62,752 male people and 58,845 female people. The amount of male population is more than the female one. It is potential for the area in the development of mangosteen farming business and maintaining the sustainability of mangosteen cultivation cycle in Karacak agropolitan area. Besides, the potential may support the increasing dynamic of the adult male farmers in the area.

Most people work as farmers but there are still 1,364 farmers who have no lands or about $47.8 \%$ farmers who do not cultivate their won lands. This condition is aggravated by the land ownership of less than 1 ha amounted $51.3 \%$ of the total 2,885 farmers' household, or it can be concluded that half of the amount of farmers in Karacak Village are the smallholders. As the agropolitan area, Karacak Village is an agricultural village that must be supported by the adequate agricultural institution. The external institutions assisting are PKHT-IPB, Bureau of
Horticulture Food Crops and Plantation of Bogor Regency, UPTD of Leuwiliang District, PPL (The Agricultural Extention Worker) from the Agricultural Extension Center (BPP) Leuwiliang, farmers group, association of farmers group (gapoktan) and KTNA (Farmers Contact). The institution has its own role assisting the farmers to solve the agricultural problems occuring in Karacak agropolitan area specifically related to the leading commodity that is mangosteens.

Leuwiliang District is included in the strategic commodity development zone through the agropolitan area development. Karacak village is one village located in Leuwiliang District and is the part of Agropolitan Area in Bogor Regency as the development stub of Agropolitan program in 2005. The marketing of Mangosteen Commodity has reached the overseas like Hongkong and Taiwan, also to the middle East countries. Mangosteen Development has used the Procedure Operational Standard (SOP) of Good Agricultural Practices in its cultivation. The central location of leading commodity of mangosteen is located in Leuwiliang District, Leuwisadeng District, and Cigudeg District, the development area is located in Jasinga District and Klapanunggal District. Mangosteen is included in one of the primary leading commodities in Bogor Regency in 2016, which production reached 79,927 ton (Bureau of Horticulture Food Crops and Plantation of Bogor Regency, 2016).

As leading commodity, mangosteen production has great potential to be able to increase the farmers' income. One effort of the Bureau of Agriculture of Bogor Regency to hold the integrated guidance and counselling, in $27^{\text {th }}$ February 2001 mangosteen farmers 
group of "Karya Mekar" has been established in Cengal Kampoong, Karacak Village, Leuwiliang District, with the number of members amounted 33 people.The development of mangosteen commodity has been continuing up to the rise of the initial concept development of Agropolitan Area that is realized through the Masterplan of Agropolitan Area of Bogor Regency in 2005 (Figure 1) covering nine districts including Leuwiliang District. The development projection of this area in the future can be carried out by developing either the on farm or off farm commodity and the sustainable area development. The development of this commodity is conducted by increasing the quality, quantity, and continuity of the production and raw materials provision of mangosteen. The continuity of mangosteen raw materials is required to support the development of downstream of mangosteen product.

The increase in production can be conducted by the area expansion (extensification) or the increase in productivity of each tree (intensification). The land area expansion has been conducted by distributing CV variety mangosteen seeds.. Raya (Cultivar Raya) known as Manggis Raya, is the leading local mangosteen developed by the Institute of Agriculture of Bogor (IPB).

Based on the program planning of agropolitan area development in Bogor Regency in the project period of 2005-2010, the agropolitan program in Karacak District has finished without any sustainability. The agropolitan program is held through the establishment of agropolitan POKJA strengthened by the Decision Letter of the Regent No.590/191/Kpts/Huk/2004 containing the information of cooperation between the government and the society to prepare the agropolitan area. The program is follow-up of the Decision Letter of the Minister of Agriculture No. 312/TU.210/ A/X/ 2002 on the estabishment on agropolitan area in 2002 and its position as the second hierarchy in the environment of Bogor Regency. In the establishment of agropolitan area, one village in Leuwiliang District that is Karacak Village is determined as the agropolitan area center with the mangosteen leading commodity. Karacak agropolitan area in Bogor Regency is supported by the plantation commodity that is mangosteen as the area leading commodity. The plantation sub-sector is one of the strategic sub-sectirs concerning all activities of management of natural resource, human resource, production facililites, tools and machine, cultivation, harvest, processing, and marketing related to the plantation plants (the Acts No.39 in 2014). It is mentioned further that the plantation activities will give benefit, from the economic, ecological, and social sectors, in line with the sustainable development. Sustainable development is a development concept that has become the mainstream of the world development in general including Indonesia. It can actually be seen from the implementation of development by putting forward the sustainable aspects in all sectors including plantation and industrial sectors. According to Todaro and Smith (2003), the sustainable development gives implication on the dynamic balance between the functions maintenance and transformation in the frame of fulfilling the requirement of life. The sustainable development is widely based on three pillars of development those are economy, social, and ecology 
(Munasinghe, 1993). Further Ekins and Simon (2001) mention that the sustainable development usually has three main aspects of development as follows: 1) environmental development, either in the use of resources, the protection of ecological process, the system of life support, and the biodiversity; 2) economic development to improve the quality of human life that is a development emphasizing on human as the central of attention; (3) fair social development in the distribution of development benefit covering all the society and among generations. On the program developed to support the increase in the national plantation production is the agropolitan program. The agropolitan concept is contained in the Master Plan of Agropolitan Area Development of the Ministry of Settlement and Regional Infrastructure determining the agropolitan centers, the regional units, the leading commodities, the infrastructure and institutional support. In the Master Plan, the leading commodity determination must meet the criteria as follows: the leading commodity supported by the downstream, the agrobusiness activity involving the actors and greatest society (local wisdom), and the producing economic scale for a big scale and socially accepted by the society (Adisasmita, 2007). The significane of agropolitan program including the development of Karacak agropolitan area in Bogor Regency is that the program is expected to give the wide benefit (multiplier effect) especially from the social economy aspect of the society and the own-source revenue (PAD). Thus, the effort of optimizing the development of Karacak agropolitan area of Bogor Regency needs to be continuously conducted to be able to increase the standard of life of the farmers community and to increase the own-source revenue from the plantation sub-sector. Therefore, it needs to conduct many analysis and evaluations to Karacak agropolitan program in Bogor Regency to be more optimal and to be able to reach the goal as have been planned. One of which is the sustainable level analysis. The result of sustainability of each dimension is then made in a kite diagram to see the tradeoff of the sustainability of Karacak agropolitan area development in Bogor Regency. The analysis result of the sustainability of Karacak agropolitan area development in Bogor Regency, which is evaluated based on five aspects includes the aspects of environment, economy, social, technology and infrastructure, and policy, as presented in Table 4 as follows.

Table 4. Analysis Result of Sustainability of Karacak Agropolitan Area Development

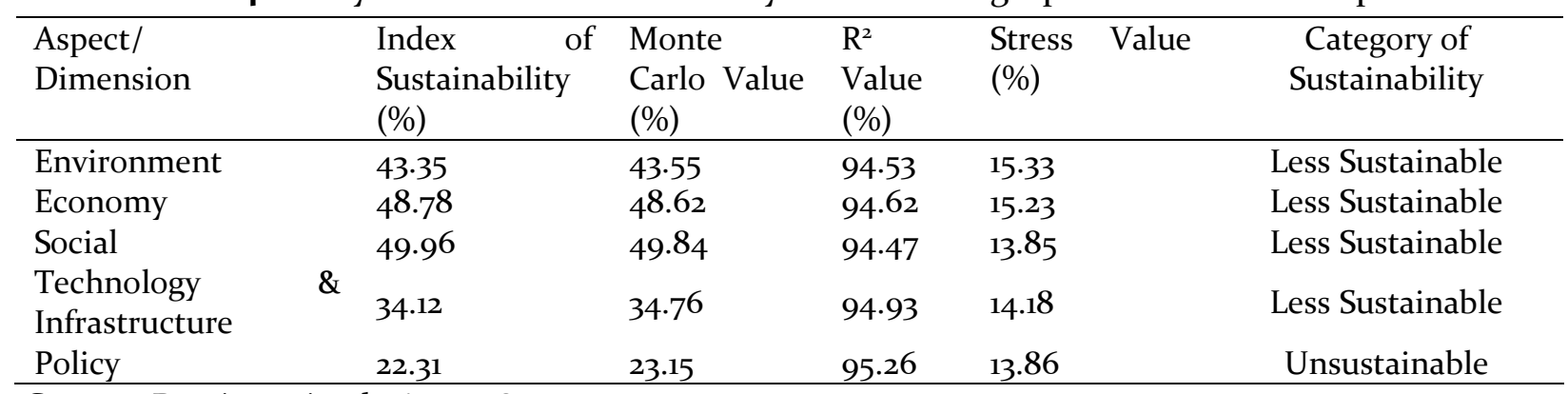

Source: RapAgro Analysis, 2018 
The result indicates that the sustainability of Karacak agropolitan area development in Bogor Regency is categorized unsustainable or less sustainable with the index value of

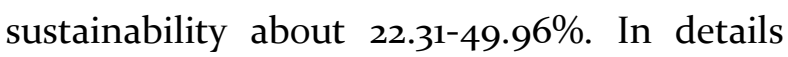
the key attribute or the lever of sustainable level of each aspect reviewed is presented in Table 5 .

Table 5. Key Attribute at Aspect of Research Review

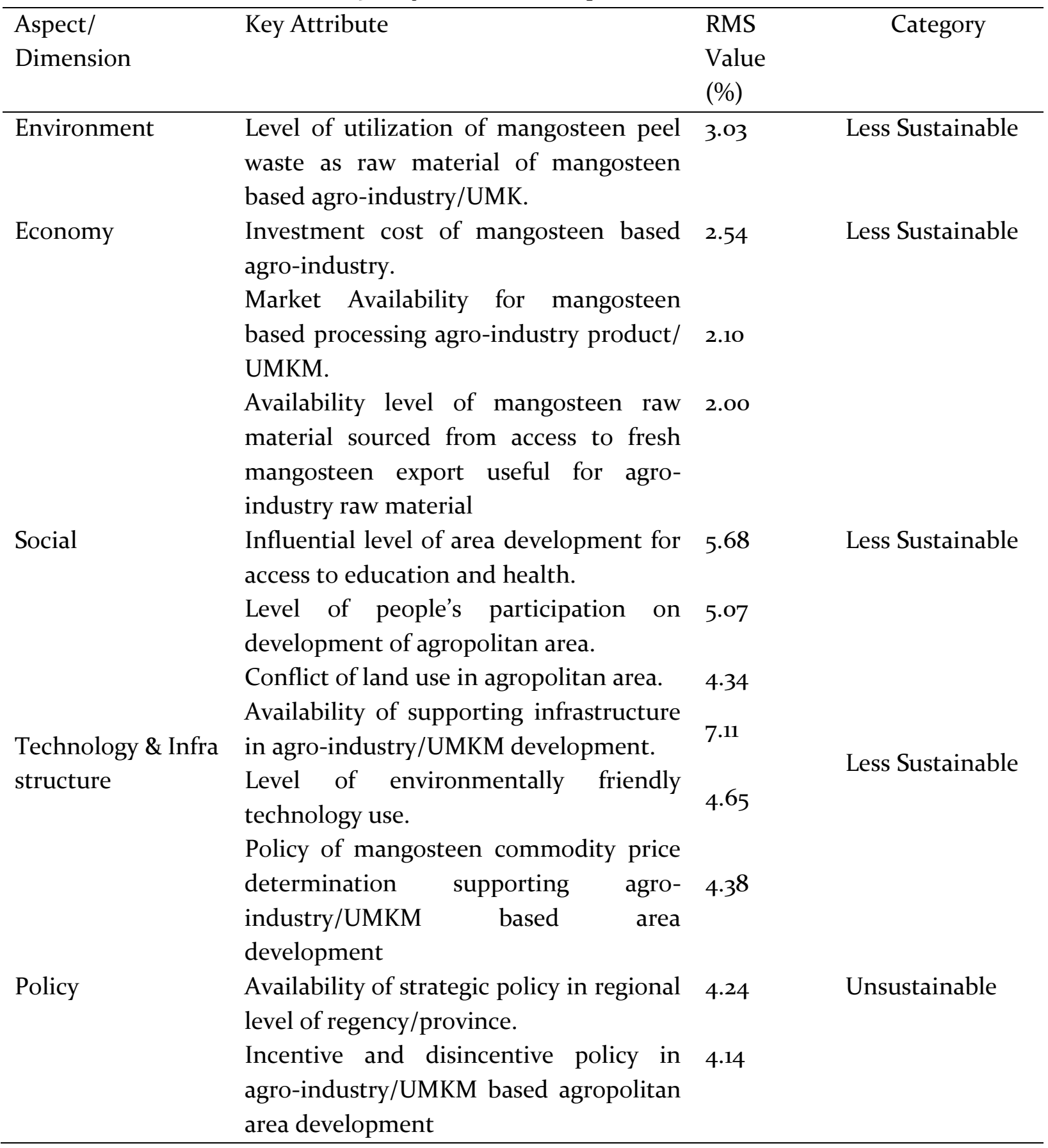


The result of analysis can be accepted based on the result of validation test found from the difference between Monte Carlo value and the index of sustainability (ordination value) about $0.12-0.84 \%$ or $<1 \%$. Kavanagh (2001) mentions that the difference between Monte Carlo value nad the ordination value is maximally $5 \%$. The value indicates that the galat effect (error) or the impact of mistake in giving the very relatively little score. Thus, RapAgro model developed is stated adequate as the estimator of sustainable index value.

The output of $\mathrm{R}^{2}$ value is found more or less between $94.47-95.26 \%$ indicating that the value is high enough of $>80 \%$. Kavanagh (2001) mentioned that Squared Correlation $\left(\mathrm{R}^{2}\right)$ value is more than $80 \%$ indicating that the estimator model of sustainable index is good and adequate to use.

The output in the form of stress value of five aspects reviewed is found more or less between $13.85-15.33 \%$ indicating that the nonconfomity criteria is categorized quite appropriate. Kavanagh (2001) mentions that the stress value tolerated is $<20 \%$.

Based on the three criteria of output validation/analysis result, it can be concluded that the model produced is valid and adequate as the estimator. The difference between Monte Carlo value and the sustainable value for all aspects of review is $<5 \%$. It is similar to the $\mathrm{R}^{2}$ that all reach $>80 \%$, and the stress value $<20 \%$. The overall sustainability of the development of the agropolitan area in Karacak, Bogor Regency is categorized as unsustainable and less sustainable. From the sustainability trade off it is obtained that the policy aspect is the aspect having the lowest sustainability level of $\mathbf{2 2 . 3 1 \%}$ or categorized as unsustainable. While the other four aspects are categorized unsustainable with the indexes ranging from 34.12 to $49.96 \%$. The condition of the trade off in the sustainability of Karacak agropolitan area development indicates that the whole aspects need to have serious attention, starting from the aspects of policy, technology and infrastructure, social, economic and social. The policy aspect becomes an aspect that needs to have the most attention in the sustainability of Karacak agropolitan area development because this aspect is categorized unsustainable. Therefore, this aspect is the basis of the study in this dissertation. The policy is more emphasized on the regional economic policies by including the agro-industry aspect to the aspect of agropolitan area development, so that these two aspects can support Karacak agropolitan sustainability.

On the policy aspect there is the lever attribute or the key attribute of sustainability that is the policy of pricing the mangosteen commodity that supports the development of agro-industry based areas, the availability of strategic policies in the regency / province level, and the incentive policies in the development agro-industry-based agropolitan area. Of the three lever attributes and some other data related to the previous analysis, it will then be used as the material for formulating the alternative of policies to select a priority policy that can be used as a direction for the economic development of the mangosteen agro-industry based sustainable aagropolitan area of Karacak.

The economic and social aspects are the biggest aspects closest to sustainability compared to the other three aspects, although they are still categorized as less sustainable. The thing supporting these two aspects is the existence of mangosteen farming that has supported Karacak agropolitan area from 
generation to generation, so that mangosteen has economically contributed to their livelihood. The social aspects is reflected by the dynamics of farmer groups that are still active and increasingly developing into a combination of farmer groups (Gapoktan) of Karya Mekar Karacak Village led by Mr. Bakri. The dynamics of farmer groups and mangosteen cultivation cannot be separated, both are interrelated and supportive each other. The lever attribute of the social aspect is the level of influence of regional development on the access to education and health, the level of people's participation in the agropolitan area development and the land use conflicts in the agropolitan area. The lever attribute of the economic aspect is the cost of mangosteen-based agro-industry investment, the availability of markets for agro-industry products and mangosteen-based processing MSMEs, and the level of availability of mangosteen raw materials sourced from the export excess of fresh mangosteen that can be used for agro-industry raw materials.The environmental aspect is also quite large approaching the sustainable category although it is still less sustainable. The lever attribute of the environmental aspect is the level of utilization of mangosteen peel waste as the raw material for agro-industry and mangosteen-based MSMEs.

The thing that supports the sustainability of this aspect is the mangosteen nursery business carried out by the farmer groups and Karacak agropolitan area community. In addition, there is also the support of the local government in the assistance program for horticulture plants and plantations for the farmers and the community. Other environmental programs has started to be driven by the environmental task force by synergizing with the farmer groups in the environmental management and the waste management in Karacak agropolitan area. In general, the agropolitan echo that is actually a national program is almost unheard today. The infrastructure and facilities previously constructed exist as if they are only used during the program. In other words, the optimization the utilization of infrastructure and facilities seems to be stagnant after the program is over. This condition is unfortunate because the investment is a high-value asset that should be used optimally and continuously in order to support the agricultural development, especially in the agropolitan program area.

It is necessary to review and find a model that can re-earth the agropolitan area development program so that it becomes a sustainable national program. The requirement is the existence of government policies that have strong legal legitimacy and support and collaboration from all stakeholders involved. The agropolitan program should be synergized with the concept of economic development through a collaboration with the local leading commodity based agroindustry in order to achieve a successful representation of the target or goal of the agropolitan area development. The implementation of this program is that the existence of agropolitan program assets must be optimally utilized and it needs the additional development of information and communication networks (IT), technology, and other physical 
infrastructure supporting the agro-industry development.

Mangosteen products are a leading product of Karacak agropolitan area that has attraction and uniqueness value compared to other regions in Bogor Regency because it has the potential of mangosteen commodities traditionally cultivated by the local indigenous people as the main farming in gardens and yards. A financial analysis of mangosteen farming has ever been investigated by Fauzan A (2011) by assuming a 20-year project period, and the results show an average net profit per year of Rp 66,096,770.00; NPV of Rp. 43,544,536; B / C ratio of 3.57; IRR of 9.54\%; and PBP for 12 years 5 months. The results of analysis indicate that under normal conditions mangosteen cultivation is feasible to be implemented. The selling price of mangosteen at the farm level is assumed to be $\mathrm{Rp} 500$ / fruit and will increase by Rpıo / fruit every 5 years.

The large potential of mangosteen is a source of raw materials for mangosteen-based agro-industry. But so far the observations and research have shown that the management of the off farm side of mangosteen is not optimal in Karacak agropolitan area. Therefore, this research studies a policy direction to encourage the establishment of mangosteenbased agro-industries in the agropolitan area one of which is to answer the optimization of the use of mangosteen as a regional leading product. So the investment analysis needs to be conducted to find out the benefits and value of benefits for the investors or the interested parties to establish the agroindustries. The results of the investment feasibility analysis can be used as a proposal or information for the parties involved in the management of Karacak agropolitan area.

Processing mangosteen fruit with a scale of home industry has not provided the optimal results. This means that it has not been able to give a double impact on the environment around the area. Therefore, to obtain a high selling value and to be able to create a multiplier effect for the region, it needs to be increased to an industrial scale. This is because Mangosteen has characteristics that are easy to experience browning process, so processing mangosteen must be stable to obtain its visual interest side. Therefore, processing through an agro-industry scale approach needs to be conducted.

The characteristics of the mangosteen flesh are quickly turning brown, having the water content of $96 \%$, having fiber and seed content. If the concentrate is taken, it is only about $3 \%$ of the initial weight of the fresh Mangosteen fruit. The peel cannot be made into drink or food because it tastes bitter. So the best alternative to take the fully valuable benefits of mangosteen peel is by processing it into preparations, both in the form of capsules, tea, and xanthones syrup. The xanthone content is almost all of the mangosteen peel. But many products being circulated in the market with the brand xanthone only contain 3\% of mangosteen peel extract, the rest is a mixture of other simplicia extracts such as soursop. Thus, the approriate product form to process mangosteen peel into mangosteen peel extract is in the form of drug preparations, and the product must be registered to BPOM as medicine. Mangosteen peel extract is interesting to be used as traditional medicine in capsule dosage form. 
The development of mangosteen peel extract industry in capsule preparations requires indepth analysis support, especially if it is associated with the development of Karacak agropolitan areas that has the potential as a provider of raw materials that is fresh mangosteen. The extracted mangosteen peel extract products going to be developed for the region are high value products. Mangosteen peel is a waste product or waste from the consumption of fresh or processed mangosteen fruit. In addition to leather waste, fresh whole fruit from low-grade export residues can also be used as raw material for the agro-industry.

The very cheap price of remaining export mangosteen when sold directly in the market is a strong reason to use it as a processed product of mangosteen peel, thus giving a greater output for Karacak agropolitan area. In Karacak agropolitan area itself there has already been processed mangosteens those are mangosteen dodol and mangosteen peel extract. Both types of products are carried out with the scale of regional women's MSME businesses.

Empowering women in economy like this needs to be supported to develop that will eventually becomes a driver of the regional economy. However, the two products have not beenanalyzed yet for business feasibility if they want to be scaled up to become agroindustries in the region. So these products need to be analyzed. The feasibility analysis of agro-industry investment in this research includes three types of mangosteen derivative products those are mangosteen dodol, mangosteen peel extract cleanser and capsulated mangosteen peel extract. The assumptions for calculating the value of each investment are presented in Table 6 . The basic assumptions used are the researcher's simulations based on any information collected from studies at the agro-industry level and the scale of mangosteen-based SMEs in Bogor Regency.

Mangosteen peel extract cleaners have already existed in Karacak agropolitan area although they have only been processed with simple technology and the business scale is still relatively small, so that the production has not been continuous, and still has some obstacles including marketing, quality and capital. While the capsulated mangosteen peel extract is a mangosteen derivative product proposed through this research. The product has not been produced in Karacak agropolitan area.

Through this study it is directed to be developed into an agro-industry that can be implemented in Karacak agropolitan area. The feasibility analysis of agro-industry investment is conducted by the analysis tools in the form of financial feasibility criteria and regional economic values. It is intended to find out how feasible the mangosteen-based agroindustry is so that it becomes the information for the public and the investors or the private sector in making investment decisions in the agropolitan area.

Mangosteen dodol products and The results of analysis obtained indicate that the mangosteen peel extract agro-industry is feasible with the parameters of $B$ / C ratio of 1.39 and the duration of return on investment of 1.025 years. Compared to the dodol and 
mangosteen peel floor cleaner agro-industry, the added value of mangosteen peel extract agro-industry is still higher and the value of the benefits is also greater for health.

Table 6. Assumption of Investment Cost of Mangosteen Product

\begin{tabular}{lcccc}
\hline Agro-industry Product & $\begin{array}{c}\text { Investment } \\
\text { Value (Rp) }\end{array}$ & Fixed Cost (Rp) & $\begin{array}{c}\text { Variable Cost } \\
(\mathrm{Rp})\end{array}$ & $\begin{array}{c}\text { Spending/ } \\
\text { Year (Rp) }\end{array}$ \\
\hline Mangosteen Dodol & $984,725,000$ & $\mathbf{1 , 9 7 0 , 3 7 9 , 7 5 0}$ & $\mathbf{2 , 2 5 6 , 1 2 0 , 0 0 0}$ & $\mathbf{4 , 2 2 6 , 4 9 9 , 7 5 0}$ \\
Floor Cleaner Soap of & $\mathbf{1 , 4 4 7 , 8 4 0 , 0 0 0}$ & $\mathbf{2 , 0 4 7 , 0 3 2 , 4 0 0}$ & $\mathbf{2 , 3 1 8 , 9 2 7 , 2 0 0}$ & $\mathbf{4 , 3 6 5 , 9 5 9 , 6 0 0}$ \\
EKM & & & & \\
Mangosteen Peel & $\mathbf{5 , 2 0 0 , 0 0 0 , 0 0 0}$ & $\mathbf{3 , 9 6 3 , 0 8 0 , 0 0 0}$ & $5,196,000,000$ & $\mathbf{9 , 1 5 9 , 0 8 0 , 0 0 0}$ \\
Extracted Capsule & & & & \\
\hline
\end{tabular}

Dodol and mangosteen peel extract cleaner agro-industries have a high vulnerability to fluctuations in raw material prices and product price competition in the market with similar products. In general, the results of the investment feasibility analysis of the three products are presented in Table 7 . Dodol mangosteen and mangosteen peel extracted cleaner agro-industries are analyzed because both of these businesses have already existed in Karacak agropolitan although they are still SME scaled and not continuous. But this has provided education for the community that mangosteen can also be developed through downstreaming develop.

Table 7. Result of Investement Feasibility Analysis of Mangosteen Agro-Industry in Normal Condtion

\begin{tabular}{lrrrr}
\hline No & Criteria of Investment & \multicolumn{3}{c}{ Values of Product } \\
\cline { 3 - 5 } & & \multicolumn{3}{c}{$(\mathbf{2})$} \\
\hline 1 & PBP (Year) & 1.03 & 3.50 & 0.46 \\
2 & NPV (Rp) & $4,914,291,007$ & $1,186,600,410$ & $68,369,956,937$ \\
3 & B/C Ratio & 1.18 & 1.04 & 2.13 \\
4 & IRR (\%) & 111 & 20.2 & 223.4 \\
5 & BEP (Rp) & $42,967,849,791$ & $51,797,300,675$ & $60,914,477,799$ \\
6 & & $1,432,262$ & $3,453,153$ & 870,207 \\
& BEP (product) & & & \\
7 & & $8,595,277,500$ & $2,878,387,200$ & $114,569,200,000$ \\
\hline
\end{tabular}

Information:

Mangosteen Dodol

Mangosteen Peel Extracted Floor Cleaner

Capsulated Mangosteen Peel Extract 
If the sensitivity is withdrawn, the condition of the price drop of the product to Rp 13,000 / bottle on the mangosteen peel floor cleaner becomes inappropriate to carry out with a B / C ratio of 0.9 and NPV of IDR $2,745,885,380$. The next sensitivity is tested by the price increase of mangosteen raw material to Rp. 15,000 / kg, the price drop of products for mangosteen dodol to Rp. 25,000, and for thecapsulated mangosteen peel extract to Rp. 50,000 / pack and the interest rate rising to $20 \%$. The results are shown in Table 8 .

Table 8. Calculation Result of Sensitivity of Investment Criteria of Mangosteen Agro-Industry

\begin{tabular}{llll}
\hline No & Criteria of Investment & Values of Product & \\
\cline { 3 - 4 } & & Mangosteen Dodol & $\begin{array}{l}\text { Mangosteen } \\
\text { Extract }\end{array}$ \\
\hline 1 & PBP (Year) & 1.025 \\
2 & NPV (Rp) & -134.90 & $17,690,067,855$ \\
3 & B/C Ratio & $-1,013,423,329$ & 1.39 \\
4 & IRR (\%) & 0.95 & 102.1 \\
5 & BEP (Rp) & -116.6 & $77,685,494,941$ \\
6 & BEP (pack of product) & $58,763,377,812$ & $1,553,710$ \\
7 & Net Profit (Rp) & $2,350,535$ & $49,889,200,000$
\end{tabular}

Source of data: Result of financial feasibility analysis

In Table 8 it can be seen that mangosteen dodol agroindustry is very vulnerable to the price increase of raw materials and the price drop of products. In addition, the increase in interest rates also plays an important role in the adaptation of the agro-industry. With a B / C Ratio of 0.95 or below 1, and a NPV value that shows a minus, the mangosteen dodol industry is not feasible to run at a product price of Rp. 25,000.00. While the capsulation of mangosteen peel extract agroindustry shows that the $\mathrm{B} / \mathrm{C}$ ratio is still above the number 1 , indicating that it is still feasible and very adaptive to the increase in bank interest rates with an IRR of $102.1 \%$.
Under these conditions, this agroindustry can achieve a net profit of IDR 49,889,200,000 with an NPV value of IDR $17,690,067,855$. The feasibility analysis of agroindustry investment is significant in this research study to determine the economic value of the processed products from the regional leading commodities that is mangosteen that will be used as an icon or as a lever for the sustainability of Karacak agropolitan area. Seen from the point of view of health, education, environment, economy and social, mangosteen processed products give benefits and added value. Investment is needed for the implementation. 
The added value of each mangosteenbased product analyzed using the Hayami method in this research can be seen in Table 9.

Table 9. Added Value of Mangosteen Agro-

\begin{tabular}{llcc}
\multicolumn{4}{c}{ Industry Products } \\
\hline No & \multicolumn{1}{c}{$\begin{array}{c}\text { Agro- } \\
\text { Industry } \\
\text { Products }\end{array}$} & $\begin{array}{c}\text { Value } \\
\text { Added }\end{array}$ & $\begin{array}{c}\text { Margin } \\
\text { (Rp) }\end{array}$ \\
\hline $\mathbf{1}$ & $\begin{array}{l}\text { Mangosteen } \\
\text { Dodol }\end{array}$ & $53,677 / \mathrm{kg}$ & $89,857 / \mathrm{kg}$ \\
2 & $\begin{array}{l}\text { Floor Cleaner } \\
\text { Soap of EKM }\end{array}$ & $18,745 / \mathrm{L}$ & $33,745 / \mathrm{L}$ \\
3 & $\begin{array}{l}\text { Mangosteen } \\
\text { Peel }\end{array}$ & $90,833 / \mathrm{kg}$ & $132,833 / \mathrm{kg}$ \\
& & \\
& Extracted \\
& Capsul
\end{tabular}

The biggest added value is the capsulated mangosteen peel extract product of $\mathrm{Rp} 90,833 / \mathrm{kg}$. Then the added value of mangosteen dodol is Rp. 53,677 / kg and the smallest on the mangosteen peel extract floor cleaner soap is Rp. 18,745 / L. From the information obtained, it will give knowledge to the stakeholders to glance at the area and give serious attention to the management of natural resources as a whole in the region. Some related stakeholders in the development of agropolitan areas by making agro-industries as core development include government, private sector, BUMN / BUMD, $\mathrm{R}$ \& D, universities, farmers, SMEs, cooperatives, associations, communities, community institutions and banks. The feasibility information stating that mangosteen-based agro-industry, especially the mangosteen peel extract product, that this capsulation is feasible, becomes the capital and the basic spirit in the agropolitan region's economic development based on mangosteen peelagro-industry. Bringing mangosteen peel waste into the core of business in the region through the mangosteen peel extract agro-industry gives a multiplier effect on the development of other mangosteen-based agro-industry.

Mangosteen peel extract agro-industry becomes the most adaptive alternative to changes in some parameters of sensitivity to investment feasibility. In addition, the use of mangosteen peel into products that have high economic value can give solutions to the environmental sustainability, optimize the regional resources and encourage the creation of jobs in the agropolitan area so that the living standards of the regional community will be better. The agro-industry can be established on an industrial scale or small and medium scale industry (IKM) in Karacak agropolitan area as a buffer zone and it has a dual role in giving spirit to the regional economic growth through the development of SMEs in the region.

The role of agro-industry in general is mainly to give solutions to the results of analysis of the sustainability of Karacak agropolitan area especially on the economic aspects, because the results of analysis show that it is less sustainable. This lack on the side will be complemented by agro-industry activities as a driving force and lever for regional economic growth.

With the movement of the agro-industry sector, the added value that rotates in the region becomes more abundant from the upstream (cultivation)downstream sectors (especially agro-industry). Wages that will roll in the region are increasingly being accepted by the regional community, among others are labor wage cultivation, wages of agro-industrial 
labor both technical and operator levels and managerial levels. If more and more regional communities involved in mangosteen-based economic activities, both cultivation and agro-industry, the money rotating in the region will be even more numerous. This will increase the purchasing power of people of the region, which in turn will promote the welfare and economic sustainability of Karacak agropolitan area. The other role of the mangosteen peel extract industry is the creation of new jobs for people in Karacak agropolitan area and other surrounding areas.

Agro-industries of mangosteen dodol and mangosteen peel extract floor cleaner can be carried out using raw materials that are adjusted to the price capabilities of the SME business scale, so that SMEs in the region also become part of the regional economic improvement. By targeting the consumers and the different market levels, these SMEs can be directed towards becoming an alternative creative economy for the regional community.

In addition, these mangosteen-based SMEs may collaborate with a good partnership system with agro-industry to be able to utilize agro-industrial waste that can still be used to produce other products with SME-scale processes.

Agro-industry and UKM may coexist with their respective roles and business orientations but can still achieve the same goals in developing sustainable agropolitan economic area of Karacak. The development of the theory of agropolitan through the research of study finally has found the development of the theory of economi growth of agropolitan area through the creation of high added value conducted by the leading commodity-based agro-industry model of the agropolitan area. The model is universal, can be applied in any region adapted to commodities and characteristics of the region.

\section{CONCLUSION}

The sustainable index of the economic aspects of Karacak agropolitan area amounted 48.78 means that the status of agropolitan area for the economic development is less sustainable. The potential mangosteen as the export commodity can be optimized and followed by the downstreaming development of mangosteen products with high value added through the agroindustry approach. The capsulated mangosteen peel extracted agroindustry products have big opportunity to atrract the investor's interest because it is feasible with the NPV value of Rp 17,690,067,855 and the additional value of $\mathrm{Rp} 90,833 / \mathrm{kg}$ of raw materials.

The sustainable index value of technology and infrastructure aspects of Karacak agropolitan area is 34.12, which means that the status of agropolitan area to develop the technology and infrastructure is less sustainable. The optimalization of the role of Department of Public Works and Public Housing (PUPR) in the regional dan province level become the key element of the success, especially the support for physcial building and feasible housing for the society in agropolitan area.

The sustainable value of environmental aspect is 43.35 , which means that the status of agropolitan area to manage the environment is less sustainable. The sustainable index value of agro-industry asepct of Karacak agropolitan area is 49.96 , which means that the status of 
agropolitan area for the agro-industry dynamic development is less sustainable. The optimalization of the role of functional institutions either the instructors of agricultre, fishery, livestock, plantation, health and Family Planning, education, perkebunan, kehutanan, kesehatan dan Keluarga Berencana, pendidikan, agro-industry, development and taxes in the regional, province, or central level become the significant elements in supporting the success of economic development of agro-industrybased agropolitan area.

\section{REFERENCES}

Adisasmita H.R. (2007). Basics of Regional Economics. Jakarta (Basic Economy of Jakarta Area): Graha Ilmu.

Austin JE. (1981). Agroindustrial Project Analysis. EDI Series in Economic Development. Washington DC. Washington Pr.

[Bappeda] National Development Planning Agency and [BPS] Central Bureau of Statistics of Bogor Regency (2016). Annual Report: 2016 Regional Economic Indicators (Annual Report: Indicator of Regional Economy). Bappeda of Bogor Regency.

Borg, I., and P.J.F. Groenen. (1997). Modern Multidimensional Scaling: Theory and Applications. Springer, New York.

Chamber, Robert. (1985). Rural Development: Putting the Last First (London: Longman)

Douglass, M. (1998). A Regional Network Strategy For Reciprocal Rural-Urban Linkages: An Agenda For Policy Research With Reference To Indonesia. Third World Planning Review, 20 (1). pp. 1-25.

Ekins P, dan Simon S. (2001). Estimating Sustainability Gaps: Methods and Prelimary Application for the United Kingdom and the Netherlands. Ecology Economics 37:5-22.

Eriyatno. (2012). System Science: Improve Quality and Management Effectiveness (Systemic Science: Increasing Quality and Effectiveness of Management). Larasati L, editor. Bogor. IPB Pr.

Escobal J, Favareto A, Aguirre F, Ponce C. 2014. Linkage to Dynamic Markets and Rural Territorial
Development in Latin America. World Development 73: 44-35.

Fauzi A and Anna S. (2005). Fisheries and Marine Resource Modeling for Policy Analysis (Modeling of Fishery and Marine Resources). Jakarta. PT Gramedia General Library.

Friedmann J, Douglass M. (1978). Agropolitan Development: Towards a New Strategy for Regional Planning in Asia, in F. Lo and K. Salih, eds., Growth Pole Strategy and Regional Development Policy. Oxford: Pergamon Press, 163-192.

Ghiffari RA. 2016. Development of Eucalyptus Oil AgroIndustries in Buru Regency. Social and Behavioral Science Procedia 227: 815-823.

Gray CP, Sabur LK, Maspaitella PFL, Vartey RGC dan Simanjuntak. (1992). Introduction to Project Evaluation, PT. Gramedia, Jakarta.

Hashemianfar et.al. (2014). Farm Corporations as Agropolitan Development in Iran. Social Science $4(2) \cdot 51-67$

Hayami, Y. et al. (1987). Agricultural marketing and processing in upland Java. A perspective from a Sunda village. Coarse Grains Pulses Roots and Tuber Center (CGPRTC). CGPRT Centre. Bogor.

Ikatrinasari ZF. 2010. Rekayasa Sistem Pendukung Keputusan Intelijen Untuk Pengembangan Agropolitan Berbasis Agroindustri (Engineering of Supporting System of Intelligent Decision for Agro-Industry-Based Agropolitan Development). Dissertation. Bogor: Institut Pertanian Bogor.

Kavanagh P. (2001). Rapid Appraisal of Fisheries (Rapfish) Project. University of British Columbia, Fisheries Centre.

Machfoeds M M. 2015. Stabilizing and Decentralizing the Growth through Agro-Industrial Development. Agriculture and Agricultural Science Procedia 3: 20-25.

Machfud. 2001. Decision Support Model Engineering

FuzzyLogic Group for Essential Oil Development (Engineering of Supporting Model of Group's Decision with FuzzyLogic System: for System of Essential Oil)

Agro-Industry Development). Dissertation. Postgraduate Program. Agricultural Institute of Bogor

Manetsch TJ , Park GL. (1979). System Analysis and Simulation with Application to Economic and Social Science. Michigan State University, East Lausing, USA. 
Marimin, et al. (2015). Teknik dan Aplikasi Green Productivity in Green Industry (Technique and Application of Green Productivity on AgroIndustry). Bogor. IPB Press Publisher

Mubyarto. (1993). Twenty Years of Rural Research. (Twenty Years of Research on Rural Areas). Aditya Media Publisher, Yogyakarta.

Munasinghe, M. (1993). Environmental Economics and Sustainable Development. World Bank Environment Paper Number 3. The World Bank. Washington DC.

Regency Regional Regulation Number 19 Year (2008). About the Bogor Regency Spatial Planning for 2005-2025 (Regional Regulation of Bogor Regency No.19 in 2008 on Spatial Planning of Bogor Regency Area).

Pitcher TJ. (1999). Rapfish, A Rapid Appraisal Technique For Fisheries, And Its Application To The Code Of Conduct For Responsible Fisheries. FAO Fisheries Circular No. FIRM/C: No. 947: 47 pp.

Rustiadi, E. (2004). A Study on the Development of Model and Typology for Agropolitan Region, Ministry of Public Works, Jakarta

Rustiadi E and Dardak EE. (2008). Agropolitan: Strategy for Developing Growth Centers in Rural Areas (Agropolitan: Development Strategy of Growth Centers in Rural Areas). Bogor. Crestpent Press.

Rustiadi E and Pranoto S. (2007). Agropolitan Builds a Rural Economy (Agropolitan Builds Rural Economy). Bogor: Crestpent Pr.

Rustiadi E, Saefulhakim S and Panuju DR. (2011). Regional Planning and Development (Regional Planning and Development). Jakarta. Crestpent Pres and the Indonesian Torch Library Foundation.

Rondinelli, Dennis. (1979). Applied Policy Analysis for Integrated Regional Development Planning in the Philippines. Third World Planning Review, 1:2, 151-178.

Saaty. (1993). Decision making for leaders: Analytical Hierarchy Process for Complex Decision Making and Situations (Decision Making for the Leaders: Analytical Hierarchy Process for Decision Making and Complex Situation). Jakarta: PT. Binaman Pressindo Library.

Sa'diah SF. (2015). Management of Sustainable Agropolitan Areas in the Highlands of Tropical Rain Forest Ecosystems (Study in the Agropolitan Area of Selupu Rejang, Rejang Regency, Bengkulu Province) (Sustainable Agropolitan Area Management in Tropical Rain Forest Ecosystem of Highlands ]). Dissertation. School of Environmental Science. University of Indonesia.

Sa'diah SF, Tjiptoherijanto P, Rustiadi E, Thayib MH. (2015). Sustainable agropolitan management model in the highland of tropical rainforest ecosystem: the case of Selupu Rejang agropolitan area, Indonesia. Environmental Sciences. Vol. 28:613-622.doi:10.1016/j.proenv.2015.07.072.

Sadjad S. (2005). Potensi Desa dalam Jelajah Agropolitics (Potential Village in Agropolitic Roam). Bogor. IPB Press.

Simamora, H. (2000). Management Accounting (Management Accounting). Jakarta: Salemba Empat Publisher.

Soekartawi. (1991). Agribusiness. Theories and Applications (Agrobusiness, Theory and Application). Jakarta. PT Raja Grafindo Persada.

Soekartawi. (2000). Introduction to Agroindustry (Introduction to Agro-Industry). PT Raja Grafindo Jakarta. Jakarta.

Supriyono, RA. (2002). Cost Accounting. Yogogyarta: Liberty Publisher.

Suryaningrat IB. 2016. Raw Material Procurement on Agroindustrial Supply Chain Management: A Case Survey of Fruit Processing Industries in Indonesia. Agriculture and Agricultural Science Procedia 9: 253-257.

Sutojo S. (1991). Project Feasibility Studies, Theories and Practices (Project Feasibility Study, Theory and Practice). Jakarta. Binawan Presindo Library.

Todaro M.P. and Smith C.S. (2004). Third World Economic Development (Third World Economy Development). Jakarta: Erlangga.

Umar H. (2007). Business Feasibility Study. Jakarta. PT Gramedia Main Library.

Wibowo S. 2008. Model of Sustainable Vegetable Farming Management in the Region 
Agropolitan (Model of Sustainable Highland Vegetable Farming Management in Agropolitan Area). Dissertation. IPB.

Young, F.Y. (2009). Multidimensional scaling (MDS). University of North Carolina, Chapel Hill 